\title{
Practical Issues and Challenges in Idiopathic Pulmonary Fibrosis
}

\author{
Vincent Cottin ${ }^{a}$ Philippe Camus ${ }^{b}$ \\ ${ }^{a}$ Hospices Civils de Lyon, Hôpital Louis Pradel, Service de Pneumologie - Centre de référence national des maladies \\ pulmonaires rares, Université Claude Bernard Lyon 1, Université de Lyon, Lyon, et ${ }^{\mathrm{b}}$ Centre Hospitalier Universitaire \\ de Dijon et Université de Bourgogne, Dijon, France
}

Idiopathic pulmonary fibrosis (IPF) is a devastating disease, with a median survival from diagnosis of only 3 years [1]. Although it is a rare and somewhat orphan disease [2], its incidence, prevalence and specific mortality are rising [3-6], further increasing the many challenges faced by both patients and chest physicians. Recent evidence-based recommendations have been produced jointly by the American Thoracic Society, the European Respiratory Society, the Japanese Respiratory Society and the Latin American Thoracic Association, establishing standards for the diagnosis and management of IPF. Standardization of diagnosis criteria originally published in 2000 [7] and updated in 2011 [8] has set the stage for drug development, and one first drug (pirfenidone) has been approved in a number of countries, representing a significant achievement in the fight against IPF. However, IPF remains a diagnostic and therapeutic challenge [9-11], with often more questions raised than answers provided. Clinicians also face a number of practical situations and decisions that are not fully addressed by international guidelines $[9,12]$.

This issue of Respiration includes the first article of a thematic review series on Practical issues and challenges in IPF (table 1). This timely series authored by IPF experts will address selected practical issues, reviewing progress made in recent years and established evidence, suggesting elements of discussion in areas where evidence is still lacking and reviewing challenges that remain. In this issue, Poletti et al. [13] review the current diagnostic approach of IPF and further discuss the heterogeneity of the disease that encompasses various clinical presentations, complications, comorbidities and phenotypes, especially regarding familial pulmonary fibrosis, rapidly progressing disease and subclinical 'early' IPF, with each of them raising specific challenges for clinicians. They further critically review elements on which to discuss the indication for lung biopsy, the potential future role for cryobiopsies (a novel endoscopic technique that is currently under evaluation for diagnosing the usual interstitial pneumonia pattern), evaluation of individual prognosis in clinical practice, and the controversial issue of possible IPF and its practical management.

In the next article of the series, Antoniou and Wells [in preparation] will review the current knowledge on acute exacerbations of IPF, a dreadful complication, which warrants active biologic and clinical research [1419]. Hypotheses for etiology, a proposed approach for appropriate diagnosis and suggested management will be reviewed, as well as recently identified potential triggers such as viral infection, surgery, microaspiration, expo-

\section{KARGER}

E-Mail karger@karger.com

www.karger.com/res
(C) 2013 S. Karger AG, Basel

0025-7931/13/0861-0001\$38.00/0
Vincent Cottin

Hospices Civils de Lyon, Hôpital Louis Pradel

Service de Pneumologie - Centre de référence national des maladies pulmonaires rares

Université Claude Bernard Lyon 1, FR-69677 Lyon (France)

E-Mail vincent.cottin@chu-lyon.fr 
Table 1. Thematic review series on idiopathic pulmonary hypertension

Idiopathic pulmonary fibrosis: diagnosis and prognostic evaluation (Venerino Poletti, Forli, Italy)

Acute exacerbation of idiopathic pulmonary fibrosis (Athol Wells, London, UK, and Katerina Antoniou, Heraklion, Greece)

Idiopathic pulmonary fibrosis: from epithelial injury to disease monitoring - insights from the benchside (Bruno Crestani, Paris, France, and Martin Kolb, Hamilton, Ont., Canada)

Pulmonary hypertension in idiopathic pulmonary fibrosis (Vincent Cottin, Lyon, France)

Idiopathic pulmonary fibrosis: recent trials and current drug therapy (Luca Richeldi, Modena, Italy)

Pulmonary rehabilitation in patients with idiopathic pulmonary fibrosis (Jürgen Behr, Munich, Germany)

When pulmonary fibrosis is not idiopathic (Philippe Camus and Philippe Bonniaud, Dijon, France)

sure to peak air pollution, aerocontaminants and drugs. Crestani and Kolb [in preparation] will review the current understanding of IPF pathogenesis [20-22], with a particular focus on the mesenchymal-epithelial interplay, circulating stem cells [23] and immune dysregulation. In one of the next articles, Camus and Bonniaud [in preparation] will review the differential diagnosis of IPF, with the critical quest for identifiable causes of pulmonary fibrosis (e.g. drugs, occupational exposure and chronic hypersensitivity pneumonitis), the challenge of differentiating IPF from other chronic fibrotic lung diseases, especially nonspecific interstitial pneumonia, and the boundaries between IPF and connective tissue diseases, especially undifferentiated ones [24]. There is mounting evidence that pulmonary hypertension is frequent in patients with IPF [25], which is possibly related to common pathogenesis pathways between IPF and pulmonary hypertension, portending a poor outcome $[26$, 27], a topic that will be reviewed in the series as well [Cottin, in preparation]. Further, pulmonary hypertension may represent a potential target for therapy in IPF [28], warranting dedicated randomized clinical trials [29] with the hope of improving outcome through specific management of IPF-related pulmonary hypertension.

Two further articles by Richeldi et al. [in preparation] and by Behr et al. [in preparation] will focus on drug therapy and pulmonary rehabilitation in the management of IPF, respectively. Recent years have indeed witnessed an increasing number of clinical trials in IPF $[30,31]$, and available data synthetized in international guidelines and Cochrane reviews need updating and critical review [10]. Among those, four key clinical trials supported the efficacy and tolerability of pirfenidone [32-35], which has been approved for the treatment of IPF in several areas of the world, including Japan, Europe and Canada, with a further phase III trial being currently conducted in North America. Richeldi et al. will review the place of drug therapy in the management of IPF and discuss key issues regarding the management of case scenarios corresponding to 'probable' or 'possible' IPF according to current guidelines $[8,9]$. In addition, a number of promising drugs are currently evaluated in patients with IPF, including the triple tyrosine kinase inhibitor nintedanib [36], GS-6624 (an inhibitor of lysyl oxidase-like molecule-2), the antioxidant $\mathrm{N}$-acetylcysteine, XAQ-576 (an anti-interleukin-13 monoclonal antibody), FG-3019 (a monoclonal antibody against connective tissue growth factor), STX100 (a monoclonal antibody specific for anti- $\alpha_{\mathrm{v}}-\beta_{6^{-}}$ integrin), BMS-986202 (a lysophosphatidic acid-1 receptor antagonist), IW001 (a type-V collagen inhibitor), PRM-151 (human pentraxin) and many others (www. clinicaltrials.gov). Results from at least three ongoing phase III IPF trials will be released in 2014, demonstrating the accelerating pace of clinical research in the field of IPF, with evolving views regarding which end-points are appropriate, feasible and clinically meaningful [37-40]. In the absence of a curative treatment for IPF, a realistic goal is to reduce the rate or pace of disease progression. Apart from drug therapy, active research is also ongoing to evaluate the place of pulmonary rehabilitation to improve patients' symptoms, exercise capacity and quality of life [41].

Although most hot topics in IPF will be reviewed in this series, some other important aspects can be found elsewhere, including the development of biomarkers [42, 43], the impact of comorbidities including emphysema (syndrome of combined pulmonary fibrosis and emphysema) [44], gastroesophageal reflux [45, 46], lung cancer [47], sleep apnea, cardiovascular disease and diabetes mellitus [48], the increasing role of genetics in the pathogenesis and management of IPF $[49,50]$, comprehensive management and supportive care [51, 52], or possible approaches for earlier diagnosis and treatment [53]. We hope readers will enjoy this series on IPF, and that it will translate into better care for IPF patients. 


\section{References}

1 Mura M, Porretta MA, Bargagli E, Sergiacomi G, Zompatori M, Sverzellati N, Taglieri A, Mezzasalma F, Rottoli P, Saltini C, Rogliani P: Predicting survival in newly diagnosed idiopathic pulmonary fibrosis: a 3-year prospective study. Eur Respir J 2012;40:101-109.

-2 Spagnolo P, du Bois R, Cottin V: Rare lung disease and orphan drug development. Lancet Respir Med 2013, in press.

-3 Coultas DB, Zumwalt RE, Black WC, Sobonya RE: The epidemiology of interstitial lung diseases. Am J Respir Crit Care Med 1994;150:967-972.

4 Navaratnam V, Fleming KM, West J, Smith CJ, Jenkins RG, Fogarty A, Hubbard RB: The rising incidence of idiopathic pulmonary fibrosis in the U.K. Thorax 2011;66:462-467.

$>5$ Gribbin J, Hubbard RB, Le Jeune I, Smith CJP, West J, Tata LJ: Incidence and mortality of idiopathic pulmonary fibrosis and sarcoidosis in the UK. Thorax 2006;61:980-985.

$\checkmark 6$ Nalysnyk L, Cid-Ruzafa J, Rotella P, Esser D: Incidence and prevalence of idiopathic pulmonary fibrosis: review of the literature. Eur Respir Rev 2012;21:355-361.

7 American Thoracic Society. Idiopathic pulmonary fibrosis: diagnosis and treatment. International consensus statement. American Thoracic Society (ATS), and the European Respiratory Society (ERS). Am J Respir Crit Care Med 2000;161:646-664.

$>8$ Raghu G, Collard HR, Egan JJ, Martinez FJ, Behr J, Brown KK, Colby TV, Cordier JF, Flaherty KR, Lasky JA, Lynch DA, Ryu JH, Swigris JJ, Wells AU, Ancochea J, Bouros D, Carvalho C, Costabel U, Ebina M, Hansell DM, Johkoh T, Kim DS, King TE Jr, Kondoh Y, Myers J, Muller NL, Nicholson AG, Richeldi L, Selman M, Dudden RF, Griss BS, Protzko SL, Schunemann HJ: An Official ATS/ ERS/JRS/ALAT statement: idiopathic pulmonary fibrosis: evidence-based guidelines for diagnosis and management. Am J Respir Crit Care Med 2011;183:788-824.

$>9$ Wells AU: Managing diagnostic procedures in idiopathic pulmonary fibrosis. Eur Respir Rev 2013;22:158-162.

10 Behr J: Evidence-based treatment strategies in idiopathic pulmonary fibrosis. Eur Respir Rev 2013;22:163-168.

11 du Bois RM: An earlier and more confident diagnosis of idiopathic pulmonary fibrosis. Eur Respir Rev 2012;21:141-146.

$\checkmark 12$ Ryerson CJ, Urbania TH, Richeldi L, Mooney JJ, Lee JS, Jones KD, Elicker BM, Koth LL, King TE Jr, Wolters PJ, Collard HR: Prevalence and prognosis of unclassifiable interstitial lung disease. Eur Respir J 2013, E-pub ahead of print.

$>13$ Poletti V, Ravaglia C, Buccioli M, Tantalocco P, Piciucchi S, Dubini A, Carloni A, Chilosi M, Tomassetti S: Idiopathic pulmonary fibrosis: diagnosis and prognostic evalution. Respiration 2013;86:5-12.
14 Judge EP, Fabre A, Adamali HI, Egan JJ: Acute exacerbations and pulmonary hypertension in advanced idiopathic pulmonary fibrosis. Eur Respir J 2012;40:93-100.

15 Collard HR, Moore BB, Flaherty KR, Brown KK, Kaner RJ, King TE Jr, Lasky JA, Loyd JE, Noth I, Olman MA, Raghu G, Roman J, Ryu JH, Zisman DA, Hunninghake GW, Colby TV, Egan JJ, Hansell DM, Johkoh T, Kaminski N, Kim DS, Kondoh Y, Lynch DA, MullerQuernheim J, Myers JL, Nicholson AG, Selman M, Toews GB, Wells AU, Martinez FJ: Acute exacerbations of idiopathic pulmonary fibrosis. Am J Respir Crit Care Med 2007;176: 636-643.

16 Antoniou KM, Cottin V: The challenge of acute exacerbation of pulmonary fibrosis. Respiration 2012;83:13-16.

17 Simon-Blancal V, Freynet O, Nunes H, Bouvry D, Naggara N, Brillet PY, Denis D, Cohen Y, Vincent F, Valeyre D, Naccache JM: Acute exacerbation of idiopathic pulmonary fibrosis: outcome and prognostic factors. Respiration 2012;83:28-35.

18 Song JW, Hong SB, Lim CM, Koh Y, Kim DS: Acute exacerbation of idiopathic pulmonary fibrosis: incidence, risk factors and outcome. Eur Respir J 2011;37:356-363.

19 Pitsiou G, Papakosta D, Bouros D: Pulmonary hypertension in idiopathic pulmonary fibrosis: a review. Respiration 2011;82:294-304.

20 Günther A, Korfei M, Mahavadi P, von der Beck D, Ruppert C, Markart P: Unravelling the progressive pathophysiology of idiopathic pulmonary fibrosis. Eur Respir Rev 2012;21: $152-160$.

21 Richeldi L, Collard HR, du Bois RM, Jenkins G, Kolb M, Maher TM, Raghu G, Vancheri C, Laurent GJ: Mapping the future for pulmonary fibrosis. Eur Respir J 2013, E-pub ahead of print.

22 Wuyts WA, Agostini C, Antoniou K, Bouros D, Chambers R, Cottin V, Egan J, Lambrecht B, Lories R, Parfrey H, Prasse A, Robalo-Cordeiro C, Verbeken E, Verschakelen J, Wells A, Verleden G: The pathogenesis of pulmonary fibrosis: a moving target. Eur Respir J 2013;41: 1207-1218.

23 Tzouvelekis A, Ntolios P, Bouros D: Stem cell treatment for chronic lung diseases. Respiration 2013;85:179-192.

24 Cottin V: Significance of connective tissue disease features in pulmonary fibrosis. Eur Respir Rev 2013, in press.

25 Kimura M, Taniguchi H, Kondoh Y, Kimura T, Kataoka K, Nishiyama O, Aso H, Sakamoto K, Hasegawa Y: Pulmonary hypertension as a prognostic indicator at the initial evaluation in idiopathic pulmonary fibrosis. Respiration 2013;85:456-463.

26 Savale L, Bertoletti L, Cottin V: Should we screen for pulmonary hypertension at the initial evaluation of idiopathic pulmonary fibrosis? Respiration 2013;85:452-455.
27 Nathan SD, Cottin V: Pulmonary hypertension in patients with idiopathic pulmonary fibrosis. Eur Respir Mon 2012;57:148-160.

$>28$ Hoeper MM, Halank M, Wilkens H, Günther A, Weimann G, Gebert I, Leuchte HH, Behr J: Riociguat for interstitial lung disease and pulmonary hypertension: a pilot trial. Eur Respir J 2013;41:853-860.

29 Cottin V: Treatment of pulmonary hypertension in interstitial lung disease: do not throw out the baby with the bath water. Eur Respir J 2013;41:781-783.

30 Richeldi L: Idiopathic pulmonary fibrosis: current challenges and future perspectives. Eur Respir Rev 2013;22:103-105.

31 Cottin V: Interstitial lung disease. Eur Respir Rev 2013;22:26-32.

32 Cottin V: Changing the idiopathic pulmonary fibrosis treatment approach and improving patient outcomes. Eur Respir Rev 2012;21: 161-167.

33 Richeldi L: Assessing the treatment effect from multiple trials in idiopathic pulmonary fibrosis. Eur Respir Rev 2012;21:147-151.

34 Taniguchi H, Ebina M, Kondoh Y, Ogura T, Azuma A, Suga M, Taguchi Y, Takahashi $\mathrm{H}$, Nakata K, Sato A, Takeuchi M, Raghu G, Kudoh S, Nukiwa T: Pirfenidone in idiopathic pulmonary fibrosis. Eur Respir J 2010;35: 821-829.

35 Noble PW, Albera C, Bradford WZ, Costabel U, Glassberg MK, Kardatzke D, King TE Jr, Lancaster L, Sahn SA, Szwarcberg J, Valeyre $\mathrm{D}$, du Bois RM: Pirfenidone in patients with idiopathic pulmonary fibrosis (CAPACITY): two randomised trials. Lancet 2011;377: 1760-1769.

36 Richeldi L, Costabel U, Selman M, Kim DS, Hansell DM, Nicholson AG, Brown KK, Flaherty KR, Noble PW, Raghu G, Brun M, Gupta A, Juhel N, Kluglich M, du Bois RM: Efficacy of a tyrosine kinase inhibitor in idiopathic pulmonary fibrosis. N Engl J Med 2011;365: 1079-1087.

37 Vancheri C, du Bois RM: A progression-free end-point for idiopathic pulmonary fibrosis trials: lessons from cancer. Eur Respir J 2013; 41:262-269.

38 Wells AU, Behr J, Costabel U, Cottin V, Poletti V, Richeldi L: Hot of the breath: mortality as a primary end-point in IPF treatment trials: the best is the enemy of the good. Tho$\operatorname{rax} 2012 ; 67: 938-940$.

>39 Raghu G, Collard HR, Anstrom KJ, Flaherty KR, Fleming TR, King TE Jr, Martinez FJ, Brown KK: Idiopathic pulmonary fibrosis: clinically meaningful primary endpoints in phase 3 clinical trials. Am J Respir Crit Care Med 2012;185:1044-1048.

40 du Bois RM, Nathan SD, Richeldi L, Schwarz MI, Noble PW: Idiopathic pulmonary fibrosis: lung function is a clinically meaningful endpoint for phase III trials. Am J Respir Crit Care Med 2012;186:712-715. 
41 Huppmann P, Sczepanski B, Boensch M, Winterkamp S, Schonheit-Kenn U, Neurohr C, Behr J, Kenn K: Effects of in-patient pulmonary rehabilitation in patients with interstitial lung disease. Eur Respir J 2012, E-pub ahead of print.

42 Maher TM: PROFILEing idiopathic pulmonary fibrosis: rethinking biomarker discovery. Eur Respir Rev 2013;22:148-152.

43 Zhang Y, Kaminski N: Biomarkers in idiopathic pulmonary fibrosis. Curr Opin Pulm Med 2012;18:441-446.

44 Cottin V: The impact of emphysema in pulmonary fibrosis. Eur Respir Rev 2013;22:153157.
5 Savarino E, Carbone R, Marabotto E, Furnari M, Sconfienza L, Ghio M, Zentilin P, Savarino $\mathrm{V}$ : Gastro-oesophageal reflux and gastric aspiration in idiopathic pulmonary fibrosis patients. Eur Respir J 2013, E-pub ahead of print.

46 Raghu G, Meyer KC: Silent gastro-oesophageal reflux and microaspiration in IPF: mounting evidence for anti-reflux therapy? Eur Respir J 2012;39:242-245.

47 Königshoff M: Lung cancer in pulmonary fibrosis: tales of epithelial cell plasticity. Respiration 2011;81:353-358.

48 Gribbin J, Hubbard R, Smith C: Role of diabetes mellitus and gastro-oesophageal reflux in the aetiology of idiopathic pulmonary fibrosis. Respir Med 2009;103:927-931.
9 Spagnolo P, Luppi F, Cerri S, Richeldi L: Genetic testing in diffuse parenchymal lung disease. Orphanet J Rare Dis 2012;7:79.

50 Devine MS, Garcia CK: Genetic interstitial lung disease. Clin Chest Med 2012;33:95-110.

51 Frank RC, Hicks S, Duck AM, Spencer L, Leonard CT, Barnett E: Ambulatory oxygen in idiopathic pulmonary fibrosis: of what benefit? Eur Respir J 2012;40:269-270.

52 Lee JS, McLaughlin S, Collard HR: Comprehensive care of the patient with idiopathic pulmonary fibrosis. Curr Opin Pulm Med 2011;17:348-354.

53 Cordier JF, Cottin V: Neglected evidence in idiopathic pulmonary fibrosis: from history to earlier diagnosis. Eur Respir J 2013, E-pub ahead of print. 